\title{
Complement metabolism in the seronegative arthritides
}

\author{
K. WHALEY, B. CANESI, ANNA MOSELEY, W. MORROW, R. STURROCK, \\ W. MITCHELL, AND W. C. DICK \\ From the University of Glasgow, Department of Pathology, Western Infirmary; the Centre for Rheumatic \\ Diseases, Baird Street; and University of Glasgow, Department of Medicine, Royal Infirmary, Castle Street, \\ Glasgow
}

The complement system, through the action of its nine components and various cleavage products, plays a major role in the inflammatory response. In rheumatoid arthritis a depression of total haemolytic complement (Hedberg, 1963, 1964, 1967; Pekin and Zvaifler, 1964; Fostiropoulos, Austen, and Bloch, 1965; Barnett, Bienenstock, and Bloch, 1966; Peltier, Coste, and Delbarre, 1966; Vaughan, Barnett, Sobel, and Jacox, 1968; Ruddy and Austen, 1970; Gligore, Bolosiu, Dutu, and Podut, 1971) and the concentrations of individual components (Fostiropoulos and others, 1965; Ruddy and Austen, 1970; Ruddy, Everson, Schur, and Austen, 1971; Britton and Schur, 1971) in synovial fluid compared with serum has been accepted as evidence of intra-articular complement activation, and has been confirmed by the finding of conversion products of C3 (Zvaifler, 1969; Hedberg, Lundh, and Laurell, 1970), cleavage products of $\mathbf{C} 5$, and the trimolecular chemotactic factor C567 (Ward and Zvaifler, 1971). Increased catabolic rates for $\mathrm{C} 3$ have also been found in synovial fluid (Ruddy, Müller-Eberhard, and Austen, 1971). In most of the above-mentioned studies, the serum complement system appeared to be normal. Activation of the complement system in the joint cavity is thought to be due to fixation by immune complexes consisting of IgG and rheumatoid factor. Although the presence of $\operatorname{IgG}$ antiglobulin factors in various seronegative arthritides has been documented (Torrigiani and Roitt, 1967; Torrigiani, Ansell, Chown, and Roitt, 1969; Torrigiani, Roitt, Lloyd, and Corbett, 1970; Panush, Bianco, and Schur, 1971), the status of the complement system in these diseases has not been described.

In this paper we report the results of measurements of the Clq, $\mathrm{C} 3$, and $\mathrm{C} 7$ components of complement, glycine-rich- $\beta$-glycoprotein (GBG or C3 proactivator) concentrations in the plasma of patients with seronegative forms of arthritis. In addition, we have used crossed antibody electrophoresis for measuring C3 conversion and immunoelectrophoresis for GBG conversion, an important index of alternate pathway activation (Götze and Müller-Eberhard, 1971).

\section{Materials and methods}

\section{PATIENTS STUDIED}

Thirty patients with ankylosing spondylitis (Gofton, 1968), nine with Reiter's disease (Bauer and Engelman, 1942), nineteen with Still's disease (Ansell and Bywaters, 1959), eighteen with psoriatic arthritis (Moll and Wright 1973), and ten with seronegative rheumatoid arthritis (Ropes, Bennett, Cobb, Jacox, and Jessar, 1958) were studied. In addition, sixteen patients with the sicca syndrome (Whaley, Williamson, Chisholm, Webb, Mason, and Buchanan, 1972) were studied as examples of localized chronic inflammatory disease controls and fourteen osteoarthritic patients acted as chronic noninflammatory joint disease controls. The mean age, duration of disease, and articular indices for these patients are shown in Table I. Of the patients with ankylosing spondilitis, seven were in stage I (disease localized to the vertebral column), eight stage II (hip joints involved), and fifteen stage III (generalized polyarthritis).

SEROLOGICAL TESTS

All patients were screened for rheumatoid factor by the Rheumaton test (Warner Laboratories), sera being tested neat and at a 1/10 dilution. Positive sera were then titrated in the R3 latex test (Denver Laboratories) starting at a dilution of $1 / 16$. Patients were said to be seropositive for rheumatoid factor when their sera produced agglutination at a titre of at least 1/16. Antinuclear factor was detected by immunofluorescence using rat kidney as substrate and screening sera at a dilution of $1 / 16$. Positive sera were titrated by quadrupling dilution until an end point of nuclear staining was achieved (Beck, 1961).

\section{COMPLEMENT STUDIES}

Serum and EDTA plasma samples were stored at $-70^{\circ} \mathrm{C}$ within 2 hrs of venepuncture, and thawed once only. All except the anticomplementary assays and the reactive lysis test for C56 assays were performed on plasma samples.

Plasma concentrations of $\mathrm{Clq}, \mathrm{C} 3$, and $\mathrm{GBG}$ were measured by radial immunodiffusion using monospecific antisera prepared as follows. 
Table I Clinical features of patients studied

\begin{tabular}{|c|c|c|c|c|c|}
\hline \multirow[b]{2}{*}{ Clinical group } & \multirow[b]{2}{*}{ No. } & \multicolumn{2}{|c|}{ Sex } & \multirow{2}{*}{$\begin{array}{l}\text { Age }(y r s) \\
\text { Mean } \pm S D\end{array}$} & \multirow{2}{*}{$\begin{array}{l}\text { Duration (yrs) } \\
\text { Mean } \pm S D\end{array}$} \\
\hline & & $M$ & $F$ & & \\
\hline Ankylosing spondylitis & 28 & 17 & 11 & $39 \cdot 1 \pm 10 \cdot 6$ & $13 \cdot 5 \pm 9 \cdot 3$ \\
\hline Reiter's disease & 10 & 10 & - & $36 \cdot 1 \pm 5 \cdot 3$ & $6 \cdot 9 \pm 7 \cdot 1$ \\
\hline Still's disease & 9 & 5 & 4 & $20 \cdot 7 \pm 9 \cdot 8$ & $11 \cdot 0 \pm 11 \cdot 4$ \\
\hline Psoriatic arthritis & 18 & 7 & 11 & $47 \cdot 1 \pm 15 \cdot 6$ & $8 \cdot 7 \pm 5 \cdot 5$ \\
\hline Seronegative RA & 10 & 4 & 6 & $32 \cdot 3 \pm 7 \cdot 8$ & $6 \cdot 4 \pm 5 \cdot 8$ \\
\hline Sicca syndrome & 16 & 1 & 15 & $57 \cdot 7 \pm 17 \cdot 9$ & $12 \cdot 9 \pm 6 \cdot 7$ \\
\hline Osteoarthritis & 14 & 4 & 10 & $63 \cdot 4 \pm 9 \cdot 2$ & $12 \cdot 4 \pm 10 \cdot 4$ \\
\hline
\end{tabular}

Clq Rabbits were immunized with latex particles agglutinated in fresh normal human serum (Thunold, Abeyounis, and Milgrom, 1970) or with purified Clq (Agnello, Winchester, and Kunkel, 1970; Yonemasu and Stroud, 1971). Sera were absorbed with lyophylized heatinactivated human serum if required.

C3 Rabbits were immunized with zymosan previously incubated in human serum (Mardiney and MüllerEberhard, 1965) or with alexinated bacteria (Thompson, 1972). Absorption with low C3-containing sera was sometimes required.

GBG Rabbits were immunized with immune precipitates prepared by immunoelectrophoresis (Goudie, Horne, and Wilkinson, 1966).

C7 Concentrations were measured in agarose plates using the reactive lysis procedure (Thompson and Lachmann, 1970). The plates contained unsensitized sheep erythrocytes, activated C56, and $0.01 \mathrm{~mol} / 1$. EDTA. Generation of C56 in agarose by certain sera was shown by reactive lysis (Thompson and Rowe, 1968).

C3 conversion was measured by crossed antibody electrophoresis (Laurell, 1965) and GBG conversion to glycine-rich $\gamma$-glycoprotein (GGG) was detected by immunoelectrophoresis. Serum anticomplementary activity was measured by incubating $0.1 \mathrm{ml}$ heat inactivated serum with 3 units of complement, and then titrating the residual complement activity.

\section{Results}

The plasma concentrations of Clq, C3, C7, and GBG are shown in Table II. High values of different components were seen in individuals in all but the disease control groups (the sicca syndrome and osteoarthritic control patients), and the mean levels of Clq, C3, and C7 were significantly higher than at least one of the control groups in the patients with ankylosing spondylitis, Still's disease, and psoriatic arthritis, whereas with the exception of the levels of $\mathrm{C} 7$ in Reiter's disease and C3 in seronegative rheumatoid arthritis no other significant differences were observed (Table II). The high levels of the individual complement components were found in patients with more widespread disease, but were not related to" clinical or laboratory parameters of disease activity. Conversion of C3 (Table III) was not present in any of the osteoarthritis or sicca syndrome plasma samples, whereas it was detected

Table II Plasma complement component concentrations in seronegative arthritides (mean $\pm S E M)$

\begin{tabular}{|c|c|c|c|c|c|c|c|c|}
\hline Component & $\begin{array}{l}\text { Normal } \\
\text { range } \\
(\% \text { of pool })\end{array}$ & $\begin{array}{l}\text { Ankylosing } \\
\text { spondylitis } \\
(\text { no. }=30)\end{array}$ & $\begin{array}{l}\text { Reiter's } \\
\text { disease } \\
(\text { no. }=9)\end{array}$ & $\begin{array}{l}\text { Still's } \\
\text { disease } \\
(\text { no. }=8)\end{array}$ & $\begin{array}{l}\text { Psoriatic } \\
\text { arthritis } \\
(\text { no. }=18)\end{array}$ & $\begin{array}{l}\text { Sero- } \\
\text { negative } \\
\text { rheumatoid } \\
\text { arthritis } \\
(\text { no. }=10)\end{array}$ & $\begin{array}{l}\text { Sicca } \\
\text { syndrome } \\
(\text { no. }=10)\end{array}$ & $\begin{array}{l}\text { Osteo- } \\
\text { arthritis } \\
(\text { no. }=14)\end{array}$ \\
\hline Clq & $70-140$ & $132 \cdot 7 \pm 7 \cdot 6^{*} \dagger$ & $128 \cdot 2 \pm 7 \cdot 8$ & $51 \cdot 7 \pm 14 \cdot 6 * \dagger$ & $128 \cdot 5 \pm 4 \cdot 0^{* *}+$ & $123 \cdot 5 \pm 5 \cdot 6$ & $113 \cdot 0 \pm 6 \cdot 8$ & $115 \cdot 2 \pm 2 \cdot 7$ \\
\hline $\mathrm{C3}$ & $\overline{70-155}$ & $\overline{148 \cdot 9 \pm 8 \cdot 6^{* * *}+\dagger \dagger}$ & $131 \cdot 7 \pm 8 \cdot 6$ & $180 \cdot 1 \pm 10 \cdot 9 * * * \dagger \dagger \dagger$ & $160 \cdot 9 \pm 12 \cdot 9 * *+\dagger \dagger$ & $136 \cdot 6 \pm 8 \cdot 9 \dagger$ & $120 \cdot 9 \pm 7 \cdot 2$ & $116 \cdot 1 \pm 7 \cdot 2$ \\
\hline $\mathrm{C7}$ & $75-155$ & $144 \cdot 3 \pm 8 \cdot 1^{* * \dagger}$ & $\overline{135 \cdot 3 \pm 10 \cdot 0 *}$ & $142 \cdot 4 \pm 15 \cdot 0^{*} \dagger$ & $136 \cdot 9 \pm 9 \cdot 2^{*}$ & $127 \cdot 7 \pm 9 \cdot 8$ & $115 \cdot 3 \pm 6 \cdot 0$ & $119 \cdot 7 \pm 6 \cdot 5$ \\
\hline GBG & $65-120$ & $105 \cdot 8 \pm 5 \cdot 1$ & $95 \cdot 6 \pm 4 \cdot 9$ & $106 \cdot 5 \pm 5 \cdot 2$ & $102 \cdot 3 \pm 4 \cdot 7$ & $99 \cdot 9 \pm 4 \cdot 2$ & $97 \cdot 0 \pm 4 \cdot 3$ & $95 \cdot 7 \pm 4 \cdot 0$ \\
\hline
\end{tabular}


Table III Complement metabolism in the seronegative arthritides

\begin{tabular}{|c|c|c|c|c|c|c|c|}
\hline & $\begin{array}{l}\text { Ankylosing } \\
\text { spondylitis }\end{array}$ & $\begin{array}{l}\text { Reiter's } \\
\text { disease }\end{array}$ & $\begin{array}{l}\text { Still's } \\
\text { disease }\end{array}$ & $\begin{array}{l}\text { Psoriatic } \\
\text { arthritis }\end{array}$ & $\begin{array}{l}\text { Sero- } \\
\text { negative } \\
R A\end{array}$ & $\begin{array}{l}\text { Sicca } \\
\text { syndrome }\end{array}$ & $\begin{array}{l}\text { Osteo- } \\
\text { arthritis }\end{array}$ \\
\hline C3 conversion & $7 / 30$ & $7 / 9$ & $4 / 9$ & $1 / 18$ & $3 / 10$ & $0 / 16$ & $0 / 14$ \\
\hline $\begin{array}{l}\text { Production of C56 in } \\
\text { agarose }\end{array}$ & $6 / 30$ & $5 / 9$ & $0 / 9$ & $6 / 18$ & $2 / 10$ & $0 / 16$ & $0 / 14$ \\
\hline $\begin{array}{l}\text { Anticomplementary } \\
\text { activity }\end{array}$ & $6 / 30$ & $3 / 9$ & ND & ND & $4 / 10$ & $0 / 16$ & $0 / 14$ \\
\hline
\end{tabular}

GBG conversion not detected in any samples.

in a variable number of samples from the other disease groups (from 1 of 19 patients with psoriatic arthritis to 7 of 9 patients with Reiter's disease). GBG conversion was not detected in any of the plasma samples studied. Reactive lysis indicating generation of C56 (Table III) was detected in certain sera from all disease groups except Still's disease, the sicca syndrome, and osteoarthritic groups. Serum anticomplementary activity (Table III) was looked for in the sicca syndrome, osteoarthritis, ankylosing spondylitis, Reiter's disease, and seronegative rheumatoid arthritis groups. In the first two groups none was detected, whereas it was found in 6 of 30 patients with ankylosing spondylitis, 3 of 9 with Reiter's disease, and 4 of 10 patients with seronegative rheumatoid arthritis.

Closer examination of the ankylosing spondylitis group of patients (Table IV) revealed that 8 of 30 patients had rheumatoid factor, detected by the Rheumaton test, present in their sera. The presence of $\mathrm{C} 3$ conversion and anticomplementary activity, and the generation of C56 in agarose were signicantly higher in this group of patients $(P<0.01$; $P<0.005$, respectively). These patients all fell into disease stage III, i.e. ankylosing spondylitis with pronounced peripheral joint involvement. In the other groups of patients with seronegative spondyloarthropathies the presence of abnormalities of the

Table IV C3 conversion, generation of C56, and serum anticomplementary activity in ankylosing spondylitis

\begin{tabular}{|c|c|c|c|}
\hline & $\begin{array}{l}\text { Rheumaton } \\
\text { positive } \\
(\text { no. }=8)\end{array}$ & $\begin{array}{l}\text { Rheumaton } \\
\text { negative } \\
\text { (no. }=22 \text { ) }\end{array}$ & Significance \\
\hline C3 conversion & 5 & 2 & $\begin{array}{l}\overline{\chi^{2}=6.6075} \\
P<0.01\end{array}$ \\
\hline C56 generation & 5 & 1 & $\begin{array}{l}\chi^{2}=8.7547 \\
P<0.005\end{array}$ \\
\hline $\begin{array}{l}\text { Anticomplemen- } \\
\text { tary activity }\end{array}$ & 5 & 1 & $\begin{array}{l}\chi^{2}=8.7547 \\
P<0.005\end{array}$ \\
\hline
\end{tabular}

complement system was also associated with widespread disease. No correlations were found between these abnormalities and ESR, serum albumin and globulin concentrations, or the presence of antinuclear factor.

\section{Discussion}

In this study we have shown that the mean circulating complement component concentrations, $\mathrm{Clq}, \mathrm{C} 3, \mathrm{C} 7$ but not GBG, are frequently raised in the seronegative arthritides. Increased serum total haemolytic complement concentration components have previouslys been found in patients with a variety of chronic inflammatory diseases, including seronegative arthritis (Vaughan, Bayles, and Favour, 1951; Laurell and Grubb, 1958; Ellis and Felix-Davies, 1959). The presence of $\mathrm{C} 3$ conversion in a significant proportion of patients with these diseases, which was not found in either of the control groups of patients with osteoarthritis or the sicca syndrome, but which has been shown to occur in the plasma of seropositive rheumatoid arthritis (Versey, Hobbs, and Holt, 1973), shows that the complement system is activated. The raised concentrations of the various components are thus probably due to increased synthesis; as has been previously shown by turnover studies of $\mathrm{C} 3$, in patients with rheumatoid arthritis (Weinstein, Peters, Brown, and Bluestone, 1971). That activation of the complement system is occurring by the classical rather than the alternate pathway is shown by the normal plasma concentrations of GBG and the absence of its conversion to GGG (Götze and Müller-Eberhard, 1971), and activation therefore is probably due to the presence of circulating immune complexes. In the ankylosing spondylitis group of patients the association of complement abnormalities with the presence of positive rheumatoid factor tests suggests that in these patients $\gamma$-globulin complexes may be responsible for activation of the system, and may play an important role in the perpetuation of the characteristic chronic inflammatory changes present in this group of arthritides. 


\section{Summary}

The plasma concentrations of Clq, C3, C7, and GBG (C3PA) have been measured in groups of patients with various seronegative spondyloarthritides. The mean levels of Clq, C3, and C7 were raised in patients with ankylosing spondylitis, Still's disease, and psoriatic arthritis, but not Reiter's disease. Evidence of complement activation was obtained by the finding of C3 conversion on crossed antibody electrophoresis. The absence of GBG conversion to GGG suggests that activation is by the classical pathway, possibly as a result of the presence of circulating immune complexes.

\section{References}

Agnello, V., Winchester, R. J., AND KunKel, H. G. (1970) Immunology, 19, 909 (Precipitin reactions of the Clq component of complement with aggregated $\gamma$-globulin and immune complexes in gel diffusion)

Ansell, B. M., AND Bywaters, E. G. L. (1959) Bull. rheum. Dis., 9, 189 (Prognosis in Still's disease)

Barnett, E. V., Bienenstock, J., AND Bloch, K. J. (1966) J. Amer. med. Ass., 198, 143 (Antinuclear factors in synovia: possible participants in the rheumatoid inclusion body)

Bauer, W., AND Engelman, E. P. (1942) Trans. Ass. Amer. Phys., 57, 307 (A syndrome of unknown aetiology characterized by urethritis, conjunctivitis and arthritis (so-called Reiter's disease))

Beck, J. S. (1961) Lancet, 1, 1203 (Variations in the morphological patterns of 'autoimmune' nuclear fluorescence)

BRITTON, M. C., AND SchUR, P. H. (1971) Arthr. and Rheum., 14, 87 (The complement system in rheumatoid synovitis. II. Intracytoplasmic inclusions of immunoglobulins and complement)

Ellis, H. A., AND FeliX-Davies, D. (1959) Ann. rheum. Dis., 18, 215 (Serum complement, rheumatoid factor, and other serum proteins in rheumatoid disease and systemic lupus erythematosus)

Fostiropoulos, G., Austen, K. F., AND BlOCH, K. J. (1965) Arthr. and Rheum., 8, 219 (Total hemolytic complement (CH 50) and second component of complement ( $\left.\mathrm{C}^{\text {' }} \mathrm{2}^{\text {hu }}\right)$ activity in serum and synovial fluid)

Gligore, V., Bolosiu, H. D., Dutu, A., AND Podut, A. (1971) Acta rheum. scand., 17, 72 (Studies on cyto-immunological changes of the synovial fluid in rheumatoid arthritis)

GofTon, J. P. (1968) 'Report from the Subcommittee on diagnostic criteria for ankylosing spondylitis', in 'Population Studies of the Rheumatic Diseases', ed. P. H. Bennett and P. H. N. Wood, p. 314. International Congress Series No. 148. Excerpta Medica, Amsterdam

GöTZE, O., AND Müller-Eberhard, H. J. (1971) J. exp. Med., 134, 90s (The C3-activator system: an alternative pathway of complement activation)

GoudIE, R. B., HoRNE, C. H. W., AND WiLkInson, P. C. (1966) Lancet, 2, 1224 (A simple method for producing antibody specific to a single selected diffusible antigen)

HeDBerg, H. (1963). Acta rheum. scand., 9, 165 (Studies on the depressed hemolytic complement activity of synovial fluid in adult rheumatoid arthritis)

(1964) Ibid., 10, 109 (The depressed synovial complement activity in adult and juvenile rheumatoid arthritis) (1967) Acta med. scand., Suppl. 479, 1 (Studies on synovial fluid in arthritis. I. The total complement activity.

II. The occurrence of mononuclear cells with in vitro cytotoxic effect)

- LundH, B., AND LAURell, A-B. (1970) Clin. exp. Immunol., 6, 707 (Studies of the third component of complement in synovial fluid from arthritic patients. II. Conversion and its relation to total complement)

LAURELl, A-B., AND GRUBB, R. (1958) Acta path. microbiol. scand., 43, 310 (Complement, complement-components, properdin and agglutination promoting factors in rheumatoid arthritis)

LAURELL, C. B. (1965) Anal. Biochem., 10, 358 (Antigen-antibody crossed electrophoresis)

MARDINEY, M. R., AND MülleR-EBerhaRd, H. J. (1965) J. Immunol., 94, 877 (Mouse $\beta_{1}$ c- globulin: production of antiserum and characterization in the complement reaction)

Moll, J. M. H., AND WRIGHT, V. (1973) Ann. rheum. Dis., 32, 181 (Familial occurrence of psoriatic arthritis)

Panush, R. S., Bianco, N. E., AND SChUR, P. H. (1971) Arthr. and Rheum., 14, 737 (Serum and synovial fluid IgG, IgA and IgM antigamma-globulins in rheumatoid arthritis)

Perin, T. J., AND ZVAIFLeR, N. J. (1964) J. clin. Invest., 43, 1372 (Hemolytic complement in synovial fluid)

Peltier, A., Coste, F., AND Delbarre, F. (1966) Presse méd., 74, 1523 (Etudes sur le complément hémolytique dans certaines maladies ostéo-articulaires. Resultats d'ensemble)

Ropes, M. W., Bennett, G. A., CoBb, S., JACoX, R., and Jessar, R. A. (1958)’Bull. rheum. Dis., 9, 75 (1958 revision of diagnostic criteria for rheumatoid arthritis)

RudDy, S., AND Austen, K. F. (1970) Arthr. and Rheum., 13, 713 (The complement system in rheumatoid synovitis. I. An analysis of complement component activities in rheumatoid synovial fluids)

—, Everson, L. K., Schur, P. H., AND Austen, K. F. (1971) J. exp. Med., 134, 259s (Hemolytic assay of the ninth complement component: elevation and depletion in the rheumatic diseases)

-, Mülller-Eberhard, H. J., AND Austen, K. F. (1971) Arthr. and Rheum., 14, 410 (Direct measurement of intraarticular hypercatabolism of the third complement component in rheumatoid arthritis and systemic lupus erythematosis) 
THompson, R. A. (1972) Immunology, 22, 147 (C3 inactivating factor in the serum of a patient with chronic hypocomplementaemic proliferative glomerulo-nephritis)

- , AND LACHMANN, P. J. (1970) J. exp. Med., 131, 629 (Reactive lysis: the complement-mediated lysis of unsensitised cells. I. The characterization of the indicator factor and its identification as C7)

-, AND ROWE, D. S. (1968). Immunology, 14, 745 (Reactive haemolysis-a distinctive form of red cell lysis)

Thunold, S., ABeYounIs, C. J., AND MILGROM, F. (1970) J. Immunol., 104, 685 (Reactions in agarose gel between Clq and aggregated $\gamma$-globulin)

Torrigiani, G., Ansel, B. M., Chown, E. E. A., AND RoItt, I. M. (1969) Ann. rheum. Dis., 28, 424 (Raised IgG antiglobulin factors in Still's disease)

- , AND RoITT, I. M. (1967) Ibid., 26, 334 (Antiglobulin factors in sera of patients with rheumatoid arthritis and normal subjects: quantitative estimation in different immunoglobulin classes)

,-- LLOYD, K. N., AND CORBETT, M. (1970) Lancet, 1, 14 (Elevated IgG antiglobulins in patients with seronegative rheumatoid arthritis)

Vaughan, J. H., BARNett, E. V., Sobel, M. V., AND Jacox, R. F. (1968) Arthr. and Rheum., 11, 125 (Intracytoplasmic inclusions of immunoglobulins in rheumatoid arthritis and other diseases)

- Bayles, T. B., AND Favour, G. B. (1951) Amer. J. med. Sci., 222, 186 (Serum complement in rheumatoid arthritis)

Versey, J. M. B., Hobes, J. R., AND Holt, P. J. L. (1973). Ann. rheum. Dis., 32, 557 (Complement metabolism in rheumatoid arthritis. I. Longitudinal studies)

WARD, P. A., AND ZvaIfLer, N. J. (1971) J. clin. Invest., 50, 606 (Complement-derived leukotactic factors in inflammatory synovial fluids of humans)

Weinstein, A., Peters, D. K., Brown, D. L., ANd Bluestone, R. (1971) Clin. Sci., 40, 12P (Complement metabolism in rheumatoid arthritis)

Whaley, K., Williamson, J., Chisholm, D. M., Webb, J., Mason, D. K., and Buchanan, W. W. (1972) Quart.J. Med., 42, 279 (Sjøgren's syndrome. I. Sicca components)

YoNemasu, K., AND STROUd, R. M. (1971) J. Immunol., 106, 304 (Clq: rapid purification method for preparation of monospecific antisera and for biochemical studies)

ZVAIFLER, N. J. (1969) J. clin. Invest., 48, 1532 (Breakdown products of C’3 in human synovial fluids) 